University of Nebraska - Lincoln

DigitalCommons@University of Nebraska - Lincoln

Agronomy \& Horticulture -- Faculty Publications

Agronomy and Horticulture Department

$1-1986$

Inheritance of Dhurrin Content in Mature Sorghum Leaves

Herman J. Gorz

United States Department of Agriculture

Francis A. Haskins

University of Nebraska-Lincoln, fhaskins@neb.rr.com

K. P. Vogel

United States Department of Agriculture, kvogel1@unl.edu

Follow this and additional works at: https://digitalcommons.unl.edu/agronomyfacpub

Part of the Plant Sciences Commons

Gorz, Herman J.; Haskins, Francis A.; and Vogel, K. P., "Inheritance of Dhurrin Content in Mature Sorghum Leaves" (1986). Agronomy \& Horticulture -- Faculty Publications. 250.

https://digitalcommons.unl.edu/agronomyfacpub/250

This Article is brought to you for free and open access by the Agronomy and Horticulture Department at DigitalCommons@University of Nebraska - Lincoln. It has been accepted for inclusion in Agronomy \& Horticulture -Faculty Publications by an authorized administrator of DigitalCommons@University of Nebraska - Lincoln. 


\title{
Inheritance of Dhurrin Content in Mature Sorghum Leaves ${ }^{1}$
}

\author{
H. J. Gorz, F. A. Haskins, and K. P. Vogel ${ }^{2}$
}

\begin{abstract}
Seedlings of both KS8 and N32 sorghum [Sorghum bicolor $\left(L_{\text {L. }}\right.$ Moench] were high in dhurrin [ $p$-hydroxy-(S)-mandelonitrile- $\beta$ D-glucoside] and thus in hydrocyanic acid potential (HCN-p), but the HCN-p of mature leaves from field-grown plants of KS8 was only about one-tenth as high as that of N32. A study of the inheritance of this large difference between KS8 and N32 revealed that a single major gene pair was responsible. There were no obvious maternal effects and $F_{1}$ 's were generally intermediate in HCN-p level between the two parents, indicating that neither high nor low HCN-p was completely dominant. HCN-p level was influenced by genetic background since mean values of the low and intermediate HCN-p classes increased slightly as the proportion of genetic background ascribable to N32 was increased. A survey of 102 additional sorghums revealed that the gene for low HCN-p carried by KS8 does not appear to occur widely because KS8 had the lowest $\mathrm{HCN}$-p of all entries assayed.
\end{abstract}

Additional index words: Cyanogenesis, Genetics, Hydrocyanic acid, $p$-Hydroxybenzaldehyde, Prussic acid, Sorghum bicolor (L.) Moench, Spectrophotometric assay.

$\mathrm{T}^{\mathrm{H}}$ $\mathrm{HE}$ biosynthesis of the cyanogenic glucoside, dhurrin [ $p$-hydroxy-(S)-mandelonitrile- $\beta$-D-glucoside], in sorghum [Sorghum bicolor (L.) Moench] has been studied extensively, and much has been learned about the process (1). However, studies of the inheritance of dhurrin content in this species have been much less conclusive. Nass (10) reviewed published reports on the inheritance of cyanogenesis in sorghum, various Lotus species, and Trifolium repens L., and concluded that the situation in sorghum was more complex than that in other species. There was general agreement that the hydrocyanic acid potential (HCN-p) of sorghum leaves was a heritable trait, but the reports failed to agree on such matters as dominance of low or high HCN-p and the number of genes involved. Lack of agreement may have been due in part to differences among the various studies with respect to lines and cultivars used, conditions of growth and sampling, and analytical procedures.

Krauss (7) concluded that HCN-p in sorghum was governed by four gene pairs with additive effects and without dominance. His work was based on crosses among four sorghum cultivars differing in HCN-p. More recent reports have included information about the HCN-p of hybrids and their parents in forage sorghum $(13,15)$ and also in sudangrass and sudangrass-sorghum combinations (14), but these studies were not designed specifically to investigate the inheritance of HCN-p.

Recently Haskins et al. (4) reported that the two sorghum lines, KS 8 and N32, both had high HCNp levels as seedlings, but when upper leaves from

\footnotetext{
${ }^{1}$ Contribution from the USDA-ARS and the Nebraska Agric. Res. Div,, Lincoln, NE 68583. Published as Paper no. 7724, Journal Series, Nebraska Agric. Res. Div. The work reported was conducted under Nebraska Agric. Res. Div. Project 12-114. Received 27 Mar. 1985.

${ }^{2}$ Supervisory research geneticist, USDA-ARS; George Holmes professor of agronomy; and supervisory research geneticist, USDAARS, respectively.
}

field-grown plants were compared in mid-August, the HCN-p of KS8 was only about one-tenth as high as that of N32. The existence of this large difference suggested that these lines might be useful in a study of the inheritance of HCN-p in mature sorghum leaves.

\section{MATERIALS AND METHODS Plant Material}

The A (cytoplasmic male-sterile) and B (maintainer) lines of KS8 (11) and N32 (12) sorghum were used as parents in the initial crosses for this study. Two crosses, AKS8 $\times$ BN32 and AN32 $\times$ BKS8, were made during the summer of 1982, and the male-sterile $F_{1}$ 's were each backcrossed to both BKS8 and BN32 in 1983. Similarly, reciprocal crosses of BKS8 and BN32 were made in 1982 following hand-emasculation of florets of the female parents, and the two fertile $F_{1}$ 's produced were self-pollinated in 1983 to obtain $\mathrm{F}_{2}$ seed. Additional crosses of AKS8 $\times$ BN32 and AN32 $\times$ BKS8 also were made in 1983 to produce more $F_{1}$ seed.

Plantings of 1983 seed of the four parental lines, the two male-sterile $F_{1}$ 's, the four backcrosses, and the two $F_{2}$ 's were made in growth chambers in April, 1984 for assay of the HCN-p of seedlings prior to transplanting to the field. These plantings were made in a soil mixture, and the chambers were operated at $27^{\circ} \mathrm{C}$ with continuous cool-white fluorescent light at a flux density of approximately $150 \mu \mathrm{mol}$ $\mathrm{m}^{-2} \mathrm{~s}^{-1}$ (measured with a Li-cor Model LI-185A meter ${ }^{3}$ ), as previously described (3). Entries were planted in rows corresponding to the nursery rows into which the seedlings would eventually be transplanted. The experiment consisted of five replications, each of which included 10 rows. Eight of these were 10-plant rows-one row of each of the four backcrosses and two of each reciprocal $F_{2}$. The other two rows were eight-plant rows; one held two plants of AN32, two of BN32, and four of one $F_{1}$, while the other eight-plant row held AKS8, BKS8, and the reciprocal $F_{1}$. Except for these restrictions, assignment of the entries to rows within replications was random. The entire experiment included 10 plants of each of the four parental lines, 20 of each of the reciprocal $F_{1}$ 's, 50 of each of the four backcrosses, and 100 of each of the reciprocal $F_{2}$ 's.

First leaves of individual week-old seedlings were assayed for HCN-p by the spectrophotometric procedure of Gorz et al. (2). Seedlings were then transplanted to the greenhouse where they were allowed to grow until 21 May. At that time, plants were transplanted to rows spaced $0.76 \mathrm{~m}$ apart with a $0.61-\mathrm{m}$ spacing within rows at the University of Nebraska Field Laboratory, Mead, NE.

During the period 17 to 30 July 1984, each of the plants was sampled for HCN-p assay. With few exceptions, plants were sampled when heads were beginning to emerge from the boot. Samples consisted of the blade of the leaf just below the flag leaf. These leaf blades were excised, placed over wet sponges in an insulated box, and carried to a laboratory adjacent to the field. There the leaf blades were

\footnotetext{
${ }^{3}$ Names of products are included for the benefit of the reader and do not imply endorsement or preferential treatment by the USDA or the Univ. of Nebraska.
} 
wiped free of dust, midribs were removed and discarded, and the remaining tissue was cut into pieces 1 to $2 \mathrm{~cm}^{2}$ in area. The pieces were thoroughly mixed, and a $2.5 \mathrm{-g}$ portion from each leaf was weighed and dried for $2 \mathrm{~h}$ at $75^{\circ} \mathrm{C}$ as previously described (4). The dried samples were weighed, transferred to coin envelopes, and held in a laboratory freezer at $-18^{\circ} \mathrm{C}$ until they were ground. A small Wiley mill fitted with a $1-\mathrm{mm}$ screen was used for grinding the tissue. Ground samples were placed in small plastic vials and stored at $-18^{\circ} \mathrm{C}$ until November, 1984, when they were extracted for $\mathrm{HCN}$-p determination.

\section{Extraction and Assay of Dried Tissue}

Samples were extracted and assayed in 10 groups, with each of the five replications being divided into two groups each of which included parental, $\mathrm{F}_{1}$, backcross, and $\mathrm{F}_{2}$ entries. A 50-mg portion of each dried and ground leaf sample was weighed into a $20 \times 150-\mathrm{mm}$ test tube, $10 \mathrm{~mL}$ of distilled water was added, and tubes were shaken briskly on a Gyrotory shaker for $2 \mathrm{~h}$ at room temperature. The tissue residue was removed by filtration (Whatman no. 1 filter paper) to provide extracts for assay.

Each extract was assayed as follows: A $1-\mathrm{mL}$ portion was diluted to $10 \mathrm{~mL}$ with $0.1 \mathrm{M} \mathrm{NaOH}$. This diluted solution was allowed to stand at room temperature for at least $3 \mathrm{~h}$ to hydrolyze any dhurrin present in the extract (9). Cyanide present in the basic solution was measured by the colorimetric procedure of Lambert et al. (8) as modified in the laboratory of Dr. E. E. Conn, Univ. of California, Davis (1982, personal communication). To a $1-\mathrm{mL}$ portion of the hydrolyzed extract in a $20 \times 150-\mathrm{mm}$ test tube, $0.5 \mathrm{~mL}$ of $1 M$ acetic acid was added, followed by $5 \mathrm{~mL}$ of a solution consisting of $2.5 \mathrm{~g}$ of succinimide (Sigma Chemical Company) and $0.25 \mathrm{~g}$ of N-chlorosuccinimide (Sigma) in $1 \mathrm{~L}$ of water. A $1-\mathrm{mL}$ portion of a solution consisting of $6.0 \mathrm{~g}$ of barbituric acid (Sigma), $30 \mathrm{~mL}$ of reagent grade pyridine, and $70 \mathrm{~mL}$ of water was added. The tube was shaken vigorously and allowed to stand at room temperature for precisely $20 \mathrm{~min}$ when absorbance of the solution at $580 \mathrm{~nm}$ was read with a Spectronic 20 colorimeter. Extracts were assayed in sets of about 18 , with each set including a blank tube ( $1 \mathrm{~mL}$ of $0.1 \mathrm{M} \mathrm{NaOH})$ and a standard $(1 \mathrm{~mL}$ of $2 \times$ $10^{-5} M \mathrm{KCN}$ in $0.1 \mathrm{M} \mathrm{NaOH}$ ). The $\mathrm{A}_{580}$ of the standard was used in calculating cyanide concentrations of the tissue extracts and of the dried tissue.

Each leaf extract in one of the 10 groups of samples was diluted 10-fold with $0.1 \mathrm{M} \mathrm{NaOH}$ (as in the colorimetric assay), and the spectrum of the resulting solution was immediately scanned from 380 to $280 \mathrm{~nm}$ with a Perkin-Elmer Lambda 3 spectrophotometer. The basic solutions were allowed to stand for about $3 \mathrm{~h}$ to permit the hydrolysis of dhurrin, and spectral scans were then repeated. The gain in $A_{330}$ between initial and 3-h scans was used to calculate the amount of $p$-hydroxybenzaldehyde liberated by dhurrin hydrolysis, and cyanide level was calculated from that value (4). Results obtained in this spectrophotometric assay were compared with those obtained colorimetrically on the same 46 extracts in this group.

\section{RESULTS AND DISCUSSION}

Entry means and standard errors indicated that with respect to $\mathrm{HCN}$-p of seedling leaves and also leaves from field-grown plants, the A lines of KS 8 and N32 did not differ significantly from their $B$ line counterparts. Also the reciprocal $F_{1}$ 's involving KS8 and N32 did not differ from each other. In the absence
Table 1. Hydrocyanic acid potential (HCN-p) of first leaves of sorghum seedlings and of mature sorghum leaves at head. emergence for the KS8 and N32 parents and for the $F_{1}$, back. cross $(B C)$, and $F_{2}$ generations.

\begin{tabular}{lccc}
\hline & \multicolumn{2}{c}{ HCN-p $\dagger$} \\
\cline { 3 - 4 } Entry & $\mathrm{n}$ & $\begin{array}{c}\text { First seedling } \\
\text { leaves }\end{array}$ & $\begin{array}{c}\text { Mature leaves } \\
\text { at head-emergence }\end{array}$ \\
\hline & & $\mathrm{mg} \mathrm{kg}^{-1}$ fresh wt. & $\mathrm{mg} \mathrm{kg}^{-1}$ dry wt. \\
KS8 & 17 & $1085 \pm 49$ & $24 \pm 3$ \\
N32 & 19 & $838 \pm 21$ & $858 \pm 39$ \\
F $_{1}$ & 38 & $959 \pm 28$ & $323 \pm 12$ \\
BC to KS8 & 99 & $966 \pm 18$ & $174 \pm 17$ \\
BC to N32 & 94 & $837 \pm 16$ & $713 \pm 37$ \\
F $_{2}$ & $\mathbf{1 8 8}$ & $856 \pm 14$ & $387 \pm 24$ \\
Total & $\mathbf{4 5 5}$ & & \\
\hline
\end{tabular}

$\dagger$ Mean \pm SE.

of obvious maternal effects or differential effects of the cytoplasms on HCN-p, the assay data were com. bined as follows: a) AKS8 and BKS8, b) AN32 and BN32, c) reciprocal $F_{1}$ 's, d) backcrosses of reciprocal $F_{1}$ 's to $\left.B K S 8, e\right)$ backcrosses of reciprocal $F_{1}$ 's to $B N 32$. and $f) F_{2}$ 's from reciprocal $F_{1}$ 's.

A total of 480 seedlings were transplanted from the growth chambers, and 455 survived for sampling as field-grown plants. All data, for seedlings as well as older plants, were based on these 455 plants. Al seedling HCN-p values were high (Table 1). Leaves of week-old sorghum shoots typically have a dry mat ter content of about $11 \%$. On this basis, the HCN-p values of first seedling leaves ranged from about 7500 to $10000 \mathrm{mg} \mathrm{kg}^{-1}$ dry matter. The HCN-p of KS8 was about 1.3 times as high as that of N32 at the seedling stage. At head emergence, however, upper leaves of KS8 plants were only about 0.03 as high in HCN-p as comparable N32 leaves (Table 1). The abil. ity to synthesize and/or retain dhurrin decreased for both KS8 and N32 between the seedling stage and head emergence, but this decrease was much more pronounced for KS8.

The HCN-p values for backcross and $F_{2}$ genera tions were relatively more variable for leaves at head emergence than for seedling leaves, as shown by the magnitudes of means and standard errors in Table 1. Cursory examination of the backcross data sug. gested that unlike the values for seedling leaves, val. ues for leaves at head emergence had a bimodal dis tribution. The backcrosses to KS8 yielded progen that were either low (similar to KS8) or intermediate (similar to the $\mathrm{F}_{1}$ ) in HCN-p; backcrosses to N3? yielded either intermediate or high (similar to N32 progeny. The $\mathbf{F}_{2}$ distribution had peaks correspond ing to low, intermediate, and high HCN-p levels. These observations led to the hypothesis that a single major gene pair accounted for the difference be tween KS8 and N32 with respect to the HCN-p of upper leaves at head emergence. The HCN-p of the $F_{1}\left(323 \mathrm{mg} \mathrm{kg}^{-1}\right)$ clearly indicated, however, that ne: ther the high HCN-p of N32 nor the low value of KS8 was completely dominant.

To test the single gene hypothesis, it was necessary to classify backcross and $F_{2}$ plants as low, interme diate, or high in HCN-p. The $F_{1}$ plants would all be heterozygous for the putative gene, and the $F_{1}$ mean 
Table 2. Backcross and $F_{2}$ segregations, levels of hydrocyanic acid potential (HCN-p), and chi-square tests for goodness of fit to indicated genetic ratios. Data are based on mature sorghum leaves sampled at early head emergence.

\begin{tabular}{|c|c|c|c|c|c|c|}
\hline \multirow[b]{2}{*}{ Progeny } & \multicolumn{3}{|c|}{ HCN-p class $\dagger$} & \multirow{2}{*}{$\begin{array}{c}\text { Ratio } \\
\text { tested }\end{array}$} & \multirow[b]{2}{*}{$x^{2}$} & \multirow[b]{2}{*}{$\mathbf{P}$} \\
\hline & Low & Intermediate & High & & & \\
\hline $\mathrm{BC}$ to $\mathrm{KS} 8$ & & & & & & \\
\hline$\stackrel{\mathrm{n}}{\text { Mean }} \pm$ SE $\ddagger$ & $\begin{array}{l}46 \\
35 \pm 3\end{array}$ & $\begin{array}{l}53 \\
295 \\
\pm 20\end{array}$ & & 1L:1I & 0.49 & 0.48 \\
\hline $\begin{array}{l}\mathrm{BC} \text { to N32 } \\
\mathrm{n} \\
\text { Mean } \pm \mathrm{SE}\end{array}$ & & $\begin{array}{l}40 \\
387 \pm 18\end{array}$ & $\begin{array}{c}54 \\
954 \pm 37\end{array}$ & 1I:1H & 2.09 & 0.15 \\
\hline $\begin{array}{l}\mathrm{F}_{2} \\
\mathrm{n} \\
\text { Mean } \pm \mathrm{SE}\end{array}$ & $\begin{array}{l}44 \\
46 \pm 3\end{array}$ & $\begin{array}{c}94 \\
307 \pm 13\end{array}$ & $\begin{array}{c}50 \\
838 \pm 31\end{array}$ & 1L:2I:1H & 0.38 & 0.83 \\
\hline
\end{tabular}

$\dagger$ HCN-p class limits: Low $(\mathrm{L})-<92 \mathrm{mg} \mathrm{kg}^{-1}$; Intermediate (I) -92 to 514 $\mathrm{mg} \mathrm{kg}{ }^{-1} ; \mathrm{High}(\mathrm{H})->514 \mathrm{mg} \mathrm{kg}^{-1}$ (dry wt. basis). $\ddagger \mathrm{mg} \mathrm{kg} \mathbf{g}^{-1}$ dry wt.

$\left(323 \mathrm{mg} \mathrm{kg}^{-1}\right) \pm 3$ standard deviation units $(3 \times 77)$ was used to establish the needed class limits [the probability of an individual $F_{1}$ (heterozygous) value falling within the $F_{1}$ mean \pm 3 standard deviation units is $0.9973(6$, p. 431)]. Thus, plants that assayed from 92 to $554 \mathrm{mg} \mathrm{kg}^{-1}$ were considered to be intermediate (heterozygous), those that assayed higher than 554 were considered to be homozygous high, and those that assayed below 92 were considered to be homozygous low. This classification resulted in the segregations shown in Table 2. Chi-square values were calculated to test the goodness of fit of the various segregations to the ratios shown in the table. Satisfactory fits to the ratios were indicated in each case; therefore, the hypothesis that a single gene pair had a major influence on the difference in HCN-p between KS8 and N32 was supported. The means in Tables 1 and 2 suggest, however, that genetic background also was involved in determining HCN-p levels. Thus, mean HCN-p values for the Low classes were in the order $\mathrm{KS} 8<$ backcross to $\mathrm{KS} 8<\mathrm{F}_{2}$. Also the Intermediate classes were in the order backcross to $\mathrm{KS} 8<\mathrm{F}_{1}$ or $\mathrm{F}_{2}<$ backcross to N32. Not all of the indicated differences were statistically significant, but the trends suggested that in the Low and Intermediate classes, as the proportion of genetic background ascribable to N32 increased, HCN-p values increased.

As noted in Materials and Methods, the 46 extracts comprising one of the 10 groups of samples representing a wide range in $\mathrm{HCN}-\mathrm{p}$ were assayed spectrophotometrically as well as colorimetrically. Mean HCN-p values were $310 \mathrm{mg} \mathrm{kg}^{-1}$ for the spectrophotometric procedure and $371 \mathrm{mg} \mathrm{kg}^{-1}$ for the colorimetric assay. The relationship between the two sets of values was highly consistent, as indicated by the correlation coefficient which exceeded 0.99. Similar results were observed previously (4).

A survey of 104 sorghum lines and cultivars (KS8, N32, and 102 other entries) was conducted. Upper leaves were harvested, dried, ground, extracted, and assayed colorimetrically as in the KS8 $\times$ N32 study. The KS8 line was lowest in HCN-p of all the entries, thus, the gene for low HCN-p carried by this line does not appear to occur widely in the entries tested.

The current study and previous work (4) have shown that upper leaves of KS8 were much lower in HCN-p than those of N32. Fall-harvested KS8 tillers also were considerably lower in $\mathrm{HCN}-\mathrm{p}$ than were comparable tillers of N32 (5). A future study will be designed to determine at what point in plant development these large differences between the lines can be detected, and the extent to which the differences persist throughout the growing season. If both mainstem and tiller leaves of KS8 prove to be consistently low in HCN-p, KS8 would appear to be a promising line for use in breeding low-cyanide sorghums which would provide less dangerous forage for livestock.

\section{ACKNOWLEDGMENTS}

We thank John J. Toy and Carol A. Caha for their excellent technical assistance.

\section{REFERENCES}

1. Conn, E.E. 1981. Biosynthesis of cyanogenic glycosides. p 183-196. In B. Vennesland, E.E. Conn, C.J. Knowles, J. Westley, and F. Wissing (ed.). Cyanide in biology. Academic Press, New York.

2. Gorz, H.J., W.L. Haag, J.E. Specht, and F.A. Haskins. 1977. Assay of $p$-hydroxybenzaldehyde as a measure of hydrocyanic acid potential in sorghums. Crop Sci. 17:578-582.

3. Haskins, F.A., H.J. Gorz, and R.B. Clark. 1982. Influence of radiation level on apparent hydrocyanic acid potential of sorghum seedlings. Crop Sci. 22:101-105.

4. ---, - --, R.M. Hill, and J.B. Youngquist. 1984. Influence of sample treatment on apparent hydrocyanic acid potential of sorghum leaf tissue. Crop Sci. 24:1158-1163.

5. - - - - - - - , and - - . 1984. Effect of freezing on the hydrocyanic acid potential of field-grown sorghum tillers. Crop Sci. 24:1183-1186.

6. Hayes, H.K., F.R. Immer, and D.C. Smith. 1955. Methods of plant breeding. 2nd ed. McGraw-Hill Book Co., New York.

7. Krauss, M. 1971. Die Vererbung des Blausäuregehaltes bei Sorghum [Sorghum bicolor (L.) Moench]. Z. Pflanzenzüchtg. 66:301-311.

8. Lambert, J.L., J. Ramasamy, and J.V. Paukstelis. 1975. Stable reagents for the colorimetric determination of cyanide by modified König reactions. Anal. Chem. 47:916-918.

9. Mao, C. -H., and L. Anderson. 1965. Cyanogenesis in Sorghum vulgare. II. Mechanism of the alkaline hydrolysis of dhurrin ( $p$-hydroxymandelonitrile glucoside). J. Org. Chem. 30:603607 .

10. Nass, H.G. 1972. Cyanogenesis: Its inheritance in Sorghum bicolor, Sorghum sudanense, Lotus, and Trifolium repens-a review. Crop Sci. 12:503-506.

11. Ross, W.M., A.J. Casady, J.R. Lawless, and F.L. Barnett. 1972. 29 Sorghum parental lines. Crop Sci. 12:722.

12. --_, H.J. Gorz, F.A. Haskins, and O.J. Webster. 1980. Registration of 10 sorghum parental lines. Crop Sci. 20:834.

13. Sotomayor-Rios, A., and S. Torres-Cardona. 1984. Agronomic performance, hydrocyanic acid potential (HCN-p), and heterosis in forage sorghum hybrids. J. Agric. Univ. P.R. $68: 131-141$

14. ----, and ----. 1984. Agronomic comparison, heterosis and hydrocyanic acid potential (HCN-p) of sudangrass-sorghum and sudangrass-sudangrass hybrids and their parents. J. Agric. Univ. P.R. 68:143-155.

15. Torres-Cardona, S., A. Sotomayor-Rios, and L. Telek. 1983. Agronomic performance and hydrocyanic acid potential (HCNp) of single and three-way sorghum-forage hybrids and DeKalb hybrid SX-17. J. Agric. Univ. P. R. 67:39-49. 